\title{
The Influence Of Employee Empowerment, Ethical Climate, Organisational Support And Top Management Commitment On Employee Job Satisfaction. A Case Of Companies In The Gauteng Province Of South Africa
}

Elizabeth Chinomona, Vaal University of Technology, South Africa

Babatunde A. Popoola, Vaal University of Technology, South Africa

Emmanuel Imuezerua, Vaal University of Technology, South Africa

\begin{abstract}
Manpower is a vital possession of any organization and the survival of any organization is dependent on the quality and empowerment of its employees, presence of good ethical climate, organizational support and commitment by top management to the organisation. An enabled manpower results in an efficient and effective organization. There is an urgent need for South Africa's companies to develop cultures that foster positive work environments and increase productivity. Achieving this is not an easy task and one of the ways to developing this culture is in the area of employee empowerment, ethical climate, organizational support and top management commitment which will ultimately lead to employee job satisfaction. Hence this paper is trying to look at the influence of employee empowerment, ethical climate, organisational support and top management commitment on employee job satisfaction, an area that seem to have been neglected by researchers considering companies in the Gauteng province of South Africa. In today's work environment, employees are needed to make decisions, take initiative, take responsibility and find solutions to problems as well as being motivated and having the best interest of the company at heart. This study used a quantitative research methodology through using Smart PLS software to analyse the data. A sample of 200 registered companies in the Gauteng province was used to collect data from employees in both managerial and non-managerial positions. All the posited 4 hypotheses were supported by the data collected.
\end{abstract}

Keywords: Employee Empowerment; Ethical Climate; Organizational Support; Top Management Commitment; Employee Job Satisfaction

\section{INTRODUCTION}

1

$\mathrm{n}$ the recent years, the way employees resigned from one company only after few months or few years of working to seek for another jobs has never gone on unnoticed and this has remained an unsolvable problem by many companies in the Gauteng Province South Africa. Companies faced a difficult situation in order to do their daily operation and cost management a lot of money since they have to recruit and train new employees many times (Hedge \& Borman 2012). Employee job satisfaction is an essential variable in the empirical literature. Sarwar and Khalid (2011) espouse that the more satisfied employees is the more productive and able to achieve his or her work creatively. The weak level of employee job satisfaction is undesirable for the business owner or the management of the companies. This is because the weak level of employee job satisfaction leads to high rate of absenteeism and higher turnover (Salaz, Pfaffenberg, \& Salazar 2006; Droussiotis \& Austin 2007). On the other hand, the high level of employee job satisfaction leads to higher commitment and engagement of employees at work (Sarwar 
\& Khalid 2011). Increases of employee job satisfaction can lead to the companies saving huge amount of resources because absenteeism and turnover issues would not arise. Turnover and absenteeism is very costly for the companies. Furthermore, a successful business companies typically considers the employees as the primary source of productivity gains and such companies, regarded employees as an asset to the organization and once employees are satisfied with their job, the employees inclined to be more energetic, enthusiastic, inspired and committed to their work (Qasim, Cheema \& Syed 2013). The research report of behavioural and social science reveals that employee job satisfaction and employee job performance are positively correlated (Kiboss \& Jemiryott 2014; Bowran \& Todd 1999). Employee job satisfaction is one the key element which gives employees energy to perform and continue his job creatively. Employee job satisfaction regulates the peace of mind, foster relaxation that leads to more enthusiasm and more innovative work (Malik, Wan, Dar, Akbar \& Naseem, 2014). Given this background, this paper will be aim to look at the influence of employee empowerment, ethical climate, organizational support and top management commitment on employee job satisfaction, a case study of registered companies in the Gauteng province and also provides the research model, hypotheses development, data collection, data analysis and results interpretation.

\section{LITERATURE REVIEW}

\section{Social Learning Theory}

The Social Learning Theory (SLT) proposes that individuals working in the same work environment are exposed to similar cue from that environment. In essence, members of the same work group make use of information available to them in the immediate work context to interpret events and to develop expectations about the appropriate course of behavior and the consequences of such behavior. Therefore, employees in the same work environment tend to adapt to the norms for appropriate behavior of that environment and will more likely behave in a homogenous manner in terms of the display of deviant behaviors and helping behaviors (Brown \& Treviño 2006).

The SLT describes the manner in which individuals in the same work environment strive to emulate certain role models like their leaders or other employees within such work environment; it explains that individuals learn by paying attention to and emulating the attitudes, values and behaviors of attractive and credible models because most individuals look outside themselves to other individuals for ethical guidance (Mayer, Kuenzi, Greenbaum, Bardes and Salvado 2009). While the attraction-selection attrition (ASA) model purports that individuals are attracted to and selected into organizations and/ or work groups based on the fit between their personal preferences and characteristics and the attributes of the organization/group. Within the context of work groups, individuals who have tendencies to be deviant or helpful will be likely to be selected into groups that they fit into. They will remain as long as their behavioral tendencies fit with other group members, and those that do not fit will indulge in turnover. The result is a homogenous work group in which members have a similar orientation regarding appropriate norms of behavior (Mayer et al 2009:2). SLT therefore shows that in companies where we have high employee empowerment, ethical climate, organizational support and top management commitment will lead to high employee job satisfaction.

\section{Employee Empowerment}

The concept of empowerment was derived from alienation, industrial democracy, participative management and job enrichment. This concept has become widespread (Bartunek \& Spreitzer 2006). It concerns a form of employee involvement initiative and refers to the degree in which employees are encouraged to make certain decisions without consulting their supervisors, so that organizational dynamics are initiated at the bottom (Eisenberger, Huntingdon, Hutchinson and Sowa 1986; Michailova, 2002; Dugguh, Ayaga \& Dennis 2014; Dinc 2015). Empowerment involves giving employees the autonomy to make decisions about how they go about their daily activities (Haas, 2010). Empowerment on the other hand is the initial, fundamental and an extraordinary aspect for achievement success and growth for any organisation and enhances the productivity and this can be used as a tool through which company's objectives and goals could be achieved (Dugguh, Ayaga \& Dennis 2014).

Moreover, employees can be empowered by successful leaders and managers by making the employees feel competent and habitually consider their interests. Goodly (2008) is of the opinion that developing and empowering employees is the main leadership development factors. In addition, he believed that servant leaders mostly can improve the leadership development factors. One of the social skills of the leaders is empowering others (McCauley \& Van Velsor, 
2004), and empowering employees is one of the leaders' ability which allows them to reinforce and improve their constituents by sharing power and giving visibility and give credits to their employees (Kouzes \& Posner, 2002; Mehrabani \& Shajari 2013). According to Page \& Wong (2003), employee empowerment is a major contributor to the development of subordinates by allowing them to do extremely well by investing in themselves and even at the risk of committing errors.

Although, handling the employees is the one of the difficult tasks for the managers because of the nature of a human being. According to Akbar, Yousaf, Haq and Hunjra (2011), a problem might occur when an organization on parallel lines start work on imparting employees empowerment as well as implementing various techniques to improve performance. In this phenomenon, effort is to maintain a required level of performance from employees while having trust on them by giving empowerment for betterment of the companies. This display of trust, motivation, and decisionmaking through empowerment for achievement of performance is, therefore, an important factor in most of the companies (Ongori 2009). Therefore, lack of commitment on part of employees and frequent changes in duties by employer without willingness are obstacles to employee empowerment.

\section{Ethical Climate}

Companies are focusing more attention to ethical issues because a good work climate is evaluated as a critical factor for organizations and business problems involving ethics are increasing (Brown \& Trevino 2006; Singhapakdi, Sirgy, Lee \& Vitell 2010; Jaramillo, Mulki \& Boles 2013). Every organization has its own ethical climate. Ethical climate makes an environment that enhances ethical values, clarifies role ambiguities and provides a clear direction for ethical decision making in ethical situations enabling individuals to adore and admire their works (Khan 2012). According to Koh \& Boo (2004), if employees perceive a favourable ethical climate the employees are most likely to have a higher level of job satisfaction. Taking the right action in an organization when faced with a decision making that influences the employees is related to the work climate of the organization. Lack of ethical consistency between the organization and its employees can cause stress and dissatisfaction (Unal 2012).

According to Shapira-Lishchinsky and Rosenblatt, (2010) ethical climate is the perceptions or psychologically meaningful descriptions which employees hold concerning the ethical procedures and policies present in their organization or the perceptual lens that employees utilize in assessing a situation. Elçi and Alpkan, (2009) are also of the opinion that the ethical climate is a component of the general organizational climate and has been described as the shared perceptions of what ethically correct behaviour is and how ethical issues should be handled. Ethical climate is a concept that describes the shared perception of organizational norms, values and behaviour (Khorshid \& Mohseni 2010). A firm's ethical climate refers to the prevailing attitudes about the firm's standards concerning appropriate conduct within the firm and reflects employee perceptions of morally appropriate actions and policies observed in the workplace (Lopez, Babin, \& Chung 2009).

Furthermore, ethical climate is a part of the organizational culture. Ethical climate of an organization can be predictor of employees 'moral and immoral behaviour (Nadi \& Hazeghi 2011), and one of the variables that can be predicted by the organization ethical climate is knowledge management (Tseng \& Fan 2011). According to Valentine, Gary, Fleischman and Kidwell (2010), several studies have been conducted which argued that climate for ethics significantly influence the way employees should evaluate and behave. Being compatible with organizational needs, organizations must establish ethical environment which may increase employees' job satisfaction. Mulki, Jaramillo and Locander (2008), assert that the ethical climate is a measurable construction, which assessed the ethical perception created in an organisation and how the ethical code is maintained through a good communication policy.

\section{Organizational Support}

For organisation to survive in this turbulent business environment, each organization has to depend on their employees to adapt to organization change and make the employees feel supportive toward the organization change (Deetz 2008; Oreg \& Sverdlik 2011). One of the goals of each organization is to be competitive through having best human resources (Singh \& Singh 2010) to achieve these, organizations need to support their employees (Allen, Shore \& Griffeth 2003). According to Blancero DelCampo, Gao and Lewis (2009), organisations can support its employees through supervisors who are positive in their work related outcomes. 
When employees perceive support from their organizations they try to share their knowledge and information with peers (Ahmed, Riaz, Shaukat, \& Butt 2013) which create a good learning environment in the organization. Therefore support from organization might help employees to promote learning cultures in organizations (Islam, Aamir, Khan \& Ahmad 2013). Dawley, Houghton and Bucklew (2010) proposed that organizational support is most effective when employees and employers participate in social exchanges that benefit all parties. For instance, in exchange for salaries, benefits, and recognition of work performance. Organizations expect employees to work hard, stay dedicated and committed and to remain with their organizations with no intentions to leave the organisation because by keeping employees enables the organization to be successful (Islam, Aamir, Khan \& Ahmad 2013).

Blackmore and Kuntz (2011) posited that organisational support is an expression of the employee's belief that the organization values their contribution and provides for their welfare and theorists also consider organizational support as a transaction between the employee who provides effort and loyalty and the organization that provides socioeconomic support. Karatepe (2012) espouses that a lack of organizational support creates job dissatisfaction with the employee's career, effort and loyalty. Harris, Bianco and Julie (2011) indicated that organizational support is significantly associated with organizational commitment and so that organizational commitment will increase and organizational conflict will decrease with the increase of organisational support.

\section{Top Management Commitment}

In the recent years, the long-term survival of many organisations is considered to be inextricably linked to the ability of organisations to produce services that meet customers' quality expectations. Top management stands as the front runner of any institution, organization, company, in which the outcome is a reflection of their capability and commitment. According to Njie, Fon and Awomodu (2008:24) and Gholambreza, Borghei, Matin and Dastani (2010), top management should be responsible for training the employees to gain the skills and ability required to perform their task effectively. Top managers need to realize that empowering employees through self-managed teams; quality improvement teams and management team will bring much benefit to the organization, through individual knowledge and skills.

Management role in quality management has been highlighted as one of the crucial requirement for a successful quality improvement implementation. According to Olorunniwo and Udo (2002), the magnitude of a successful project depends on the level of top management commitment. Hence, top management commitment requires that management at all levels should reassign the role from authoritarian to coaching facilitator because top management commitment does not mean dictatorship but rather their ability to monitor and control their empowered employees and giving room for their middle and line managers to take responsibility in decision making ( Njie et al 2008).

Furthermore, when the organisation demonstrates its commitment to employees, the employees develop positive attitudes and feel committed to an organisation. Management can show its commitment to employees by increasing budget, staff support, training and compensation administration (Kanter 1968; Tavitiyaman, 2004:8). If the managers treat their employees well, employees will also treat customers well. However, many organizations do not pay much attention to management commitment and job satisfaction of frontline employees that can directly influence customer satisfaction (Malhotra \& Mukherjee, 2004; Lautizin, Laschinger \& Ravazzol 2009). Employees are likely to become committed to an organization when they feel that the organization is committed to them and support them (Fuller, Barnett, Hester, \& Relyea 2003). For the employees to deliver outstanding services, the managers and organizations must make the commitment to help the employees.

\section{Employee Job Satisfaction}

Employee job satisfaction has been a topic of great interests for researchers; therefore it has been studied across several decades. The concept was first mention and developed by Landsberger (1958) with the Hawthorne effect. It is a key part of the human by necessarily providing energy to to perform and continue in his job. Additionally, it provides him the power to develop and initiate in his job. Job Satisfaction contributes peace of mind, relaxation to the worker and this result in increased enthusiasm and focus in his work to initiate (Maher 2008). Employee job satisfaction additionally defines as a way of completeness and accomplishment stemming from work, this sense has nothing to try and do with cash. 
Meanwhile, Khuong and Tien (2013), opines that there is still no agreement in the definition of employee job satisfaction. In any field of business, job satisfaction has been a matter of concern and is the backbone for an organization's success; the key to successful organization is the secret of satisfied workers. Higher will the level of job satisfaction if the degree of the expectations being met is greater. The report reveals that from the worker's perspective, the level of job satisfaction increases when he finds his work more interesting and different (Dinler 2010).

According to Celik (2011), job satisfaction is the uppermost important target for the process of making total quality in the working environment, because the total quality is based on the sincere commitment to work. Job satisfaction is the difference between the inputs made by employee and the outputs receive from the job. When the answer comes positive then the employee is satisfied and when the answer comes negative then the employee is dissatisfied with the job (Vishwakarma, Shukla \& Nougriaya 2015). Job satisfaction and dissatisfaction does not only depend on the nature of the job, but it also depends on the expectation of what the job supply to an employee (Hussami 2008). Lower convenience costs, higher organizational and social and intrinsic reward will increase job satisfaction (Parvin \& Kabir 2011).

\section{Conceptual Model and Hypotheses Development}

Figure 1. Conceptual Model

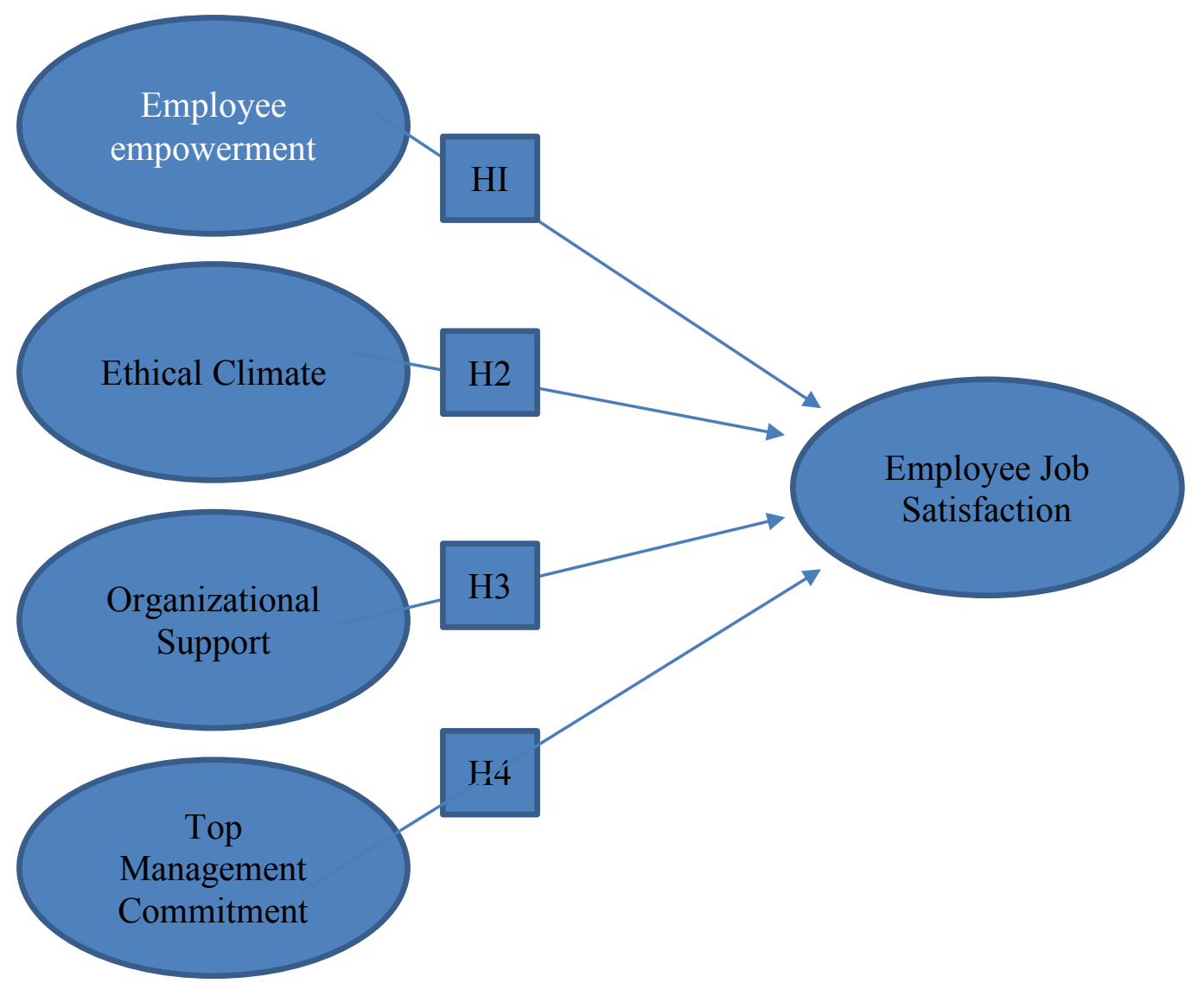

\section{Employee Empowerment and Employee Job Satisfaction}

The hypothesis developed for these concepts is based on the influence of employee empowerment on employee job satisfaction. Studies have shown that many of managers does not recognize the real importance of employee empowerment and its effect on job satisfaction on the other hand some managers believe that employee empowerment will reduce their authority (Kouzes \& Posner, 2002; Maher 2008; Man, Modrak, Dima \& Pachura 2011; Mehrabani 
\& Shajari 2013). Empowerment in the workplace is an often-misunderstood concept because is a term that many managers and organizations think they understand, but few actually do and even fewer really put it into practice (Elnaga \& Imran 2014). When employees are empowered, it increases their confidence degree and self-reliance which can result in a positive outcome because it creates job satisfaction and high levels of productivity. Yang and Choi (2009) explained that empowerment has a positive effect on employee job satisfaction. Employee empowerment will lead to improved productivity, performance and job satisfaction. According to Pieterse, Knippenberg, Schippers and Stam (2010), employee empowerment has been associated with the concept of power, implying that power in organizations should be re-shared from the top management to the lower management in order to have an employee job satisfaction. Employee empowerment means that if employees are valued in their organization, they create increased level of organizational commitment and job satisfaction (Ongori 2009).

Based on the above mentioned literature, this study posits that:

H1: There is a positive relationship employee empowerment and employee job satisfaction.

\section{Ethical Climate and Employee Job Satisfaction}

Even though there are relatively limited studies, recent studies from variety of sectors suggest that different dimensions of ethical climate have different impact on different facets of job satisfaction (Khan, 2012; Unal 2012; Zehir, Muceldili \& Zehir 2012; Monsef, Fadaei \& Pour 2014). Schwepker (2001), suggests that ethical climate positively influence ethical behaviours and may result in employee job satisfaction by eliminating ambiguities on job. Schminke, Ambrose and Neubaum (2005) opine that there is a positive and meaningful relationship between the caring and the rules, the perceptions of the ethical climate and job satisfaction. Mulki. Jaramillo and Locander (2008) also opines that a positive direction and meaningful relationship existed between the perceptions of the ethical climate and the job satisfaction. The perceptions of the ethical climate could be the determinant factor over the job satisfaction of the sales personnel in a survey conducted among the pharmacy employees in the USA. According to the study of Jaramillo, Mulki and Boles (2013), postulates that ethical climate has a positive relationship with trust in supervisors and job satisfaction. Ethical climate of an organization can have considerable impact on job satisfaction of employees.

Based on the above mentioned literature, this study posits that:

H2: There is a positive relationship ethical climate and employee job satisfaction.

\section{Organisational Support and Employee Job Satisfaction}

Organisational support has a significant impact on employee job satisfaction. In a study by Mio, Hou and Kim (2011), they found that organisational support to employees enhance their job satisfaction. Literature on organisational behaviour has confirmed a positive relationship between organisational support and employee job satisfaction (Wayne, Shore \& Liden 1997; Tekleab \& Chiaburu 2011). Robins and Judge (2009) defines job satisfaction as a positive feeling about one's job resulting from an evaluation of its characteristics. Job satisfaction can be considered as an attitudinal perception on how employees feel about their job or aspects of their job. Many studies related to the antecedents of job satisfaction have been conducted; however, one of the most important predictors of job satisfaction is organisational support (Shore \& Shore 1995; Randal, Cropanzano, Bormann, \& Birjulin, 1999; Tansky \& Cohen 2001; Rhoades \& Eisenberger, 2002; Stamper \& Johlke, 2003; Colakoglu, Culha, \& Atay, 2010). Furthermore, the employees who feel their organisation as supportive are satisfied with their job.

Based on the above mentioned literature, this study posits that:

H3: There is a positive relationship organisational support and employee job satisfaction.

\section{Top Management Commitment and Employee Job Satisfaction}

Top management commitment and employee job satisfaction are related and this can be ascertained by the previous studies which revealed that top management commitment is a significant predictor of employee job satisfaction (Chen, 
2007; Yoon \& Thye 2002; Orgambidez \& Borrego 2014). Top Management role in quality management has been highlighted as one of the crucial requirement for a successful quality improvement implementation which leads to employee job satisfaction. According to Pheng and Jasmine (2004), the degree of support that management takes in the implementation a total quality environment is very critical to the success of total quality management implementation. This cannot be fully implemented if there is lack of commitment from top management. The nature of top management commitment can bring significant change to an organisation and ultimately job satisfaction.

Based on the above mentioned literature, this study posits that:

H4: There is a positive relationship top management commitment and employee job satisfaction.

\section{RESEARCH METHODOLOGY}

The study utilized a quantitative research design using a structured questionnaire. The design was suitable to solicit the required information relating to employee empowerment, ethical climate, organizational support, top management commitment and employee job satisfaction. In addition, the approach enables to examine the causal relationships with the constructs used in the study.

\section{Data Collection}

The data for this research was collected from registered companies within the Gauteng province of South Africa. The target population was restricted to managers and non-managerial employees. The database of the companies in the Gauteng province was obtained from the Gauteng Enterprise Propeller, the Gauteng business directory as well as District municipality records as these sources provides more specific registered companies on the Gauteng province.

\section{Measurement Instrument and Questionnaire Design}

Research scales were designed on the basis of previous work. Proper modifications were made in order to fit the current research context and purpose. Employee empowerment' was measured using five-item scales adapted from Mehrabani and Shajari (2013). Ethical climate' used a five-item scale measure; all were adapted from Khan (2012). Organisational support used a five-item scale measure adapted from Mio, Hou and Kim (2011). Top management commitment was measured using a five-item scale from Chen (2007). In addition, job satisfaction was measured using a five-item scale from Khuong and Tien (2013). All were measured on a five-point Likert-type scale that was anchored by 1 (strongly disagree) to 5 (strongly agree) in order to express the degree of agreement. Out of 255 questionnaires distributed, 200 were usable representing a total of $78 \%$ response rate.

\section{DATA ANALYSIS AND RESULTS}

Table 1. Sample demographic characteristics

\begin{tabular}{c|cc}
\hline Gender & Frequency & Percentage \\
\hline Male & 110 & $55 \%$ \\
\hline Female & 90 & $45 \%$ \\
\hline Total & $\mathbf{2 0 0}$ & $\mathbf{1 0 0 \%}$ \\
\hline Age & Frequency & $27 \%$ \\
\hline$\leqq 30$ & 55 & $50 \%$ \\
\hline $31-60$ & 100 & $23 \%$ \\
\hline$\geqq 60$ & 45 & $\mathbf{1 0 0 \%}$ \\
\hline Total & $\mathbf{2 0 0}$ & Percentage \\
\hline Marital status & Frequency & $79 \%$ \\
\hline Married & 158 & $21 \%$ \\
\hline Single & 42 & $\mathbf{1 0 0 \%}$ \\
\hline Total & $\mathbf{2 0 0}$ & \\
\hline
\end{tabular}

As indicated in Table 1, this study shows that males constituted $55 \%$ of the total respondents. In terms of the age groups of respondents, individuals who were between 31 and 60 years of age were the greatest number (50\%) in the 
study, followed by those aged below 30 years (27\%) and the least were those below 60 years $(23 \%)$. Respondents who are married constituted $79 \%$ of the sample while those who were single constituted $21 \%$ of the sample.

\section{Psychometric Properties of the Measurement Scale}

Psychometric properties of the measurement scale are reported in Table 2, which presents the research constructs, Cronbach alpha test, composite reliability (CR), Average variance extracted (AVE) and item loadings.

Table 2. Measurement Accuracy Assessment and Descriptive Statistics

\begin{tabular}{|c|c|c|c|c|c|c|c|}
\hline \multirow{2}{*}{ Research constructs } & \multicolumn{2}{|c|}{$\begin{array}{c}\text { Descriptive } \\
\text { statistics* }\end{array}$} & \multicolumn{2}{|c|}{ Cronbach's test } & \multirow{2}{*}{ C.R. } & \multirow{2}{*}{ AVE } & \multirow{2}{*}{$\begin{array}{c}\text { Item } \\
\text { Loadings }\end{array}$} \\
\hline & Mean & SD & $\begin{array}{c}\text { Item- } \\
\text { total }\end{array}$ & $\alpha$ Value & & & \\
\hline \multicolumn{8}{|l|}{ Employee Empowerment(EP) } \\
\hline EP 2 & 2.60 & 1.122 & 0.601 & 0.605 & 0.606 & 0.595 & 0.701 \\
\hline EP 3 & & & 0.523 & & & & 0.575 \\
\hline EP 4 & & & 0.538 & & & & 0.564 \\
\hline EP 5 & & & 0.707 & & & & 0.772 \\
\hline \multicolumn{8}{|l|}{ Ethical Climate } \\
\hline $\mathrm{EC} 4$ & 2.15 & 1.100 & 0.905 & 0.920 & 0.920 & 0.829 & 0.927 \\
\hline EC5 & & & 0.955 & & & & 0.962 \\
\hline \multicolumn{8}{|l|}{ Organisational Support (OS) } \\
\hline OS 1 & 4.15 & 1.660 & 0.763 & 0.702 & 0.701 & 0.665 & 0.811 \\
\hline OS 2 & & & 0.843 & & & & 0.907 \\
\hline OS 3 & & & 0.531 & & & & 0.551 \\
\hline OS 4 & & & 0.722 & & & & 0.808 \\
\hline OS 5 & & & 0.857 & & & & 0.869 \\
\hline \multicolumn{8}{|c|}{ Top Management Commitment (TC) } \\
\hline TC 1 & 5.00 & 1.367 & 0.815 & 0.793 & 0.792 & 0.643 & 0.859 \\
\hline TC 2 & & & 0.693 & & & & 0.704 \\
\hline TC 3 & & & 0.849 & & & & 0.866 \\
\hline TC 4 & & & 0.807 & & & & 0.857 \\
\hline TC 5 & & & 0.864 & & & & 0.871 \\
\hline \multicolumn{8}{|l|}{ Job Satisfaction (JS) } \\
\hline JS 1 & 4.89 & 1.300 & 0.839 & 0.780 & 0.776 & 0.722 & 0.855 \\
\hline JS 2 & & & 0.556 & & & & 0.600 \\
\hline JS 3 & & & 0.602 & & & & 0.639 \\
\hline JS 4 & & & 0.629 & & & & 0.693 \\
\hline JS 5 & & & 0.751 & & & & 0.793 \\
\hline
\end{tabular}

On employee empowerment 1 item was deleted which was EP 1 and on ethical climate 3 items were deleted which was EC 1, EC 2 and EC 3 because the items factor loadings were less than 0.500 which means they explained less than $50 \%$ of the variance and did not meet the threshold of equal to or above 0.500 . The lowest item to total loading observed was EP 3 with 0.523 and the highest was EC 5 with 0.955 . The lowest factor loading observed was 0.551 and the highest is 0.962 . This shows that the measurement instruments are valid. The lowest Cronbach alpha was 0.605 and the highest was 0.920 which shows that the constructs were internally consistent or reliable and explained more that $60 \%$ of the variance. All composite reliability values were above the recommended minimum of 0.6 , which further attests to the reliability of the measurement instrument used in the study. One of the methods used to ascertain the discriminant validity of the research constructs was the evaluation of whether the correlations among latent constructs were less than 0.60 . These results are reported in Table 3 . 
Table 3. Inter-Construct Correlation Matrix

\begin{tabular}{l|l|l|l|l|l}
\hline \multicolumn{1}{|c|}{ Variables } & CL & CS & GC & GI & GS \\
\hline CL & $\mathbf{0 . 5 7 9}$ & & & & \\
\hline CS & 0.554 & $\mathbf{0 . 5 9 8}$ & & & \\
\hline GC & 0.523 & 0.560 & $\mathbf{0 . 4 3 8}$ & & \\
\hline GI & 0.473 & 0.523 & 0.443 & $\mathbf{0 . 5 6 5}$ & $\mathbf{0 . 5 9 2}$ \\
\hline GS & 0.378 & 0.375 & 0.297 & 0.549 & \\
\hline
\end{tabular}

$\overline{\mathrm{GC}}=$ Perceived Gautrain Convenience; GI= Perceived Gautrain Image; GS= Perceived Gautrain Safety; CS= Customer Satisfaction; $\mathrm{CL}=$ Customer Loyalty

A correlation value between constructs of less than 0.60 is recommended in the empirical literature to confirm the existence of discriminant validity. As can be observed from Table 3, all the correlations were below the acceptable level of 0.60. The diagonal values in bold are the Shared Variances (SV) for the respective research constructs. The Shared Variance is expected to be greater than the correlation coefficients of the corresponding research constructs. Drawing from Table 2 and 3 above, the results further confirm the existence of discriminant validity. To ascertain convergent validity, the factor loadings were considered in order to assess if they were above the recommended minimum value of 0.5 (Nunnally \& Bernstein, 1994). The factor loadings for scale items (Table 2) were above the recommended 0.5 , which indicated that the instruments were valid and converging well on the constructs that they were expected to measure.

\section{Path Modelling Results}

After confirming the reliability and validity of the measurement instruments (reported in Table 2), the study proceeded to test the proposed hypotheses. In total there are four hypotheses that are tested. In the path model, Employee Empowerment (EP), Ethical Climate (EC), Organisational Support (OS) and Top management Commitment (TC) are the predictor variables. Job satisfaction (JS) is the outcome/dependent variable. Figure 2 provides the proposed hypotheses and the respective path coefficients. The same results of the path coefficients are tabulated in Table 2 depicting the Item to Total correlations, Average variance extracted (AVE), Composite Reliability (CR) and Factor Loadings.

\section{Path Model Results and Factor Loadings}

Below is Figure 2, indicating the path modelling results and as well as the item loadings for the research constructs. In the figure, EP stands for Employee Empowerment, EC stands for Ethical Climate, OS is the acronym for Organisational Support, TC is an acronym for Top management Commitment and JS stands for Job Satisfaction. 
Figure 2. Path Modelling and Factor Loading Results

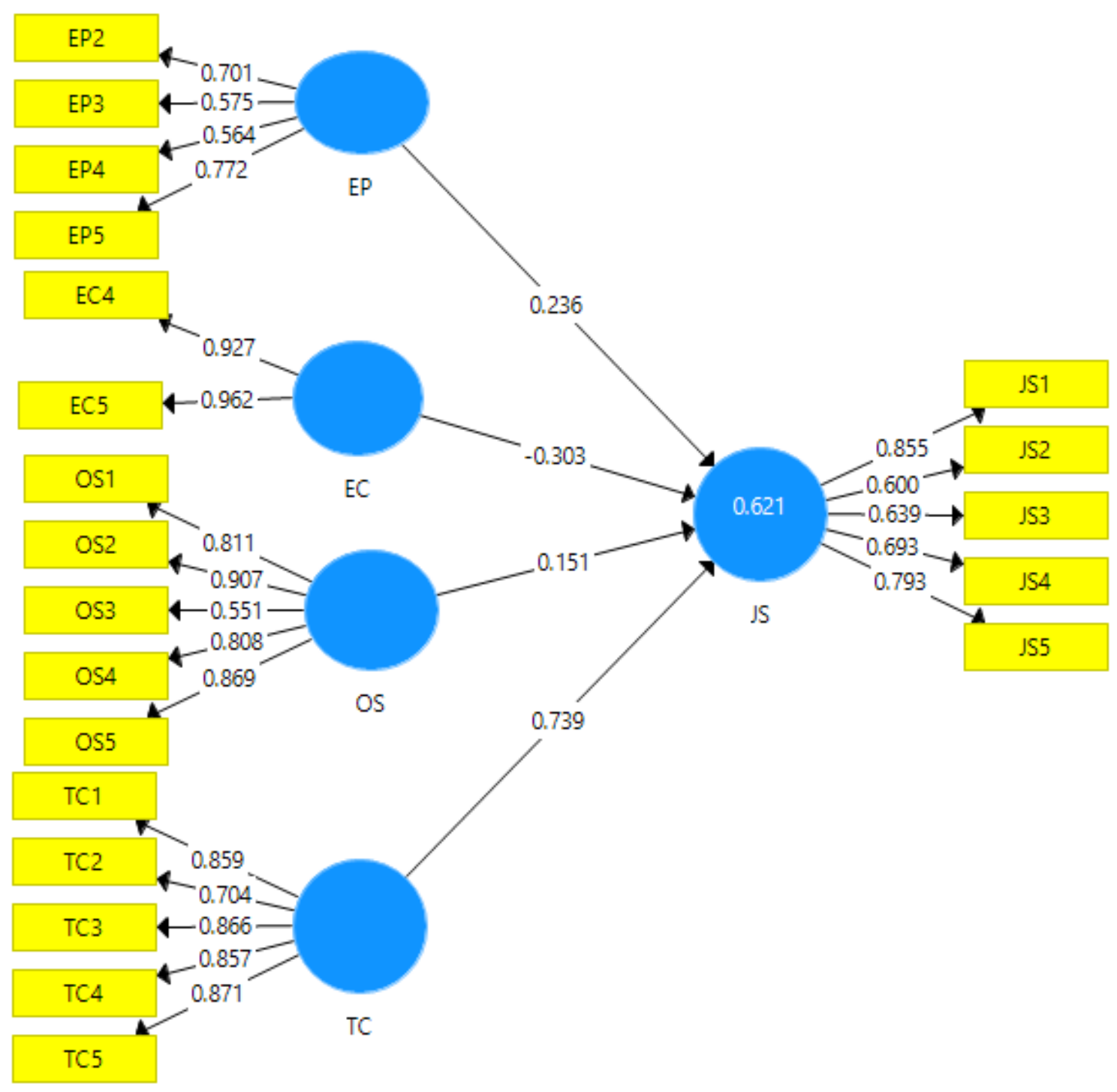

After running the data on the Smart PLS software, four items (EP 1, EC 1, EC 2 and EC 3) were deleted due to the fact that the factor loadings were below 0.5 which is the recommended minimum threshold. Based on these results, the decisions made on the hypotheses are summarized in Table 4. 
Table 4. Results of structural equation model analysis

\begin{tabular}{|c|c|c|c|c|}
\hline Path & Hypothesis & Path coefficients $(\beta)$ & T- Statistics & $\begin{array}{l}\text { Decision on } \\
\text { Hypotheses }\end{array}$ \\
\hline $\begin{array}{l}\text { Employee Empowerment }(\mathrm{EP}) \rightarrow \text { Employee } \\
\text { Job Satisfaction (JS) }\end{array}$ & H1 & $0.236^{\mathrm{a}}$ & 4.659 & $\begin{array}{c}\text { Accept/ } \\
\text { Significant }\end{array}$ \\
\hline $\begin{array}{l}\text { Ethical Climate (EC) } \rightarrow \text { Employee Job } \\
\text { Satisfaction (JS) }\end{array}$ & H2 & $0.303^{\mathrm{a}}$ & 5.610 & $\begin{array}{c}\text { Accept/ } \\
\text { Significant }\end{array}$ \\
\hline $\begin{array}{l}\text { Organisational Support (OS) } \rightarrow \text { Employee } \\
\text { Job Satisfaction (JS) }\end{array}$ & H3 & $0.151^{\mathrm{a}}$ & 3.143 & $\begin{array}{c}\text { Accept/ } \\
\text { Significant }\end{array}$ \\
\hline $\begin{array}{l}\text { Top Management Commitment (TC) } \rightarrow \\
\text { Employee Job Satisfaction (JS) }\end{array}$ & H4 & $0.739^{\mathrm{a}}$ & 14.989 & $\begin{array}{c}\text { Accept/ } \\
\text { Significant }\end{array}$ \\
\hline
\end{tabular}

${ }^{\mathrm{a}}$ Significance Level $\mathrm{p}<.10 ;{ }^{\mathrm{b}}$ Significance Level $\mathrm{p}<.05 ;{ }^{\mathrm{c}}$ Significance Level $\mathrm{p}<.01$.

Table 4 presents the four hypothesized relationships, path coefficients, the t-statistics and the decision criteria. The value of the t-statistic indicates whether the relationship is significant or not. A significant relationship is expected to have a t-statistics that is above 2. Drawing from the results provided in Table 4, four of the hypothesized relationships ( $\mathrm{H} 1, \mathrm{H} 2, \mathrm{H} 3$ and $\mathrm{H} 4)$ were statistically significant.

\section{DISCUSSION OF RESULTS}

The purpose of this paper was to examine the causal relationships between employee empowerment, ethical climate, organizational support, top management commitment and Employee job satisfaction in the registered companies that are in the Gauteng province of South Africa. The first hypothesis stated that employee empowerment has a positive influence on Job satisfaction. In this study, this hypothesis was supported. It can be observed in Figure 2 and Table 4 that perceived Gautrain convenience exerted a positive influence $(r=0.236)$ and was statistically significant $(\mathrm{t}=4.659)$ in predicting job satisfaction. This result implies that perceived employee empowerment directly influence job satisfaction in a positive and significant fashion. The higher the level of employee empowerment the higher the level of job satisfaction in the companies in the Gauteng province of South Africa.

The second hypothesis suggested that ethical climate has a positive influence on job satisfaction. This hypothesis was supported in this study. Figure 1 and Table 4, indicate that ethical climate, H2 was supported. Ethical climate exerted a positive influence $(r=0.303)$ on job satisfaction and was statistically significant $(\mathrm{t}=5.610)$. This result denotes that ethical climate is positively and significantly related to job satisfaction. Thus higher levels of ethical climate will lead to higher levels of job satisfaction.

The third hypothesis, which advanced that organisational support exerts a positive influence on job satisfaction was supported and accepted in this study. It is reported in Figure 1 and Table 4 that $\mathrm{H} 3$ organisational support exerts a positive $(r=0.151)$ influence on job satisfaction and that this influence is statistically significant $(t=3.143)$. This result suggests that organisational support has a direct positive effect on job satisfaction. Thus, the more effective the organisational support, the greater the job satisfaction of employees.

The final hypothesis postulated that top management commitment exerts a positive influence on job satisfaction. In this study, this hypothesis was supported and accepted. As can be deducted from Figure land Table 4, top management commitment exerted a positive and significant influence $(r=0.739 ; \mathrm{t}=14.989)$ on job satisfaction. This result depicts top management commitment is associated with higher job satisfaction for the employees.

Top management commitment $(r=0.739)$ emerged as the highest scoring construct amongst the three factors influencing job satisfaction. Perhaps, this result could be attributed to the fact that top management commitment influences a lot of favourable decisions for the company resulting in high job satisfaction for the workers. As shown by a previous study conducted by Kim and Brymer (2011) top management support have a significant relationship in job satisfaction. It was discovered that in order to continue having effective job satisfaction, feedback should be sought for permanent and non-permanent workers in order to consolidate this result. Ahmed, Shad, Mumtaz and Tanyeer (2012) also alluded that top management support have a significant positive relationship with job satisfaction. If there is high top management commitment in an organizational it automatically means there will be ethical climate, employee empowerment, organizational support and ultimately high job satisfaction. Thus, in order to enhance job 
satisfaction, greater emphasis should be placed on top management commitment than on employee empowerment, ethical climate and organisational support.

\section{LIMITATIONS AND FUTURE RESEARCH DIRECTION}

A number of limitations were observed during this research. First, the study was restricted to five factors only; namely employee empowerment, ethical climate, organizational support, top management commitment and job satisfaction from the perception of both employees in both managerial and non-managerial employees in the Gauteng province only. Future research could also include the perceptions of employees in other provinces like Limpopo, Mpumalanga and Eastern Cape provinces for comparison reasons. Second, the results are based on a small sample of 200 respondents, which makes it difficult to generalize the results to other contexts. Future studies could make use of amplified sample sizes in order to get more representative views. Since this study used a quantitative approach, future studies could also use a mixed method approach so that in depth views of employees can also be captured.

\section{CONCLUSIONS AND MANAGERIAL IMPLICATIONS}

The study validates that factors such as employee empowerment, ethical climate, organizational support, top management commitment and job satisfaction are instrumental in stimulating the job satisfaction of employees in the Gauteng province of South Africa. In addition, top management commitment has a stronger impact on job satisfaction when compared to employee empowerment, ethical climate and organisational support.

The study has both theoretical and managerial implications. Theoretically, this study makes a noteworthy progression in organizational behavior theory by methodically examining the interplay between employee empowerment, ethical climate, organizational support, top management commitment and job satisfaction. In this manner, the study is an important contributor to the existing literature on this subject. The study also underwrites a new direction in the research on organizational behavior by opening up a discussion on the importance of organizational practices in the development and improvement of job satisfaction in developing countries such as South Africa.

On the practical front, since employee empowerment, ethical climate, organizational support and top management commitment were exerted a having a strong positive influence on job satisfaction, improvements in each of these three factors could stimulate higher job satisfaction for the companies in the Gauteng province of South Africa. Employee empowerment can be improved by, among other things, delegating the duties to lower level employees and non-biased promotions. In addition, ethical climate could be improved by having clear cut rules and regulations and be equitable in the distribution of resources and salaries. To increase its organisational support, companies can focus more on hearing and solving employees' grievances and be participatory in whatever they do. Employees feel as part and parcel of the organisation if they are involved the decision making always. To increase top management support companies should provide extra benefits for top management like free education for the children and providing company houses and cars to for them to use.

\section{AUTHOR BIOGRAPHIES}

Dr. Elizabeth Chinomona. I am a married woman with three children. I did my first degree with the University of Zimbabwe and my Masters with National Cheng Kung University in Taiwan. Currently am working as a lecturer at Vaal University of Technology in the Logistics Department, South Africa. I graduated my PHD this year with the same university. Research is my passion as I always learnt a lot from it and also disseminate knowledge to others. My research areas are entrepreneurship, marketing, supply chain, organizational behaviour and human resources management. I have published more than 25 articles in accredited Journals and more than 10 in non-accredited Journals.

Popoola Babatunde Adedeji was born May 1980 in Nigeria where he obtained Higher National Diploma in Accounting from Federal Polytechnic Offa, Kwara State. He worked as an Accountant at Common sense Ltd, Ikeja Lagos State Nigeria for the period of 4years. He is a holder of Masters in Cost and Management Accounting from the Vaal University of Technology, also have a Baccalaureus Technology in Cost and Management Accounting, and also a graduate of Post graduate diploma in higher education (PGDHE) from the same university and he has been a key 
member of Vaal University of Technology staff since 2011 in the training of future accountants. He is a member of South Africa Institute of Professional Accountant (SAIPA), student member of Institute of Chartered Accountants of Nigeria (ICAN) and also a member of Nigerian Institute of Management (Chartered). He is a research expert who has resulted in the publication of more than four articles in accredited Journals.

Emmanuel Imuezerua. I was born in Lagos, Nigeria. My parents have five boys and four girls of which I am the eldest and we are all married. I had my primary and secondary education as well as my first degree in Accounting from Nigeria and moved to South Africa for my Masters in cost and management accounting. I am currently pursuing my $\mathrm{PhD}$ in Accounting from the University of Limpopo. I am a Lecturer at the Vaal University of Technology and I have published and co-authored a few articles in accredited journals.

\section{REFERENCES}

Ahmed, I., Riaz, T., Shaukat, M.Z \& Butt, H.A. (2013). Social exchange relations at work: A knowledge sharing and learning perspective. World Journal of Management and Behavioral Studies, 1 (1), 33-35.

Ahmed, B., Shad, I., Mumtaz, R \& Tanveer, Z. (2012). Organizational ethics and job satisfaction: evidence from Pakistan. African Journal of Business Management, 6(8).

Akbar, S.W., Yousaf, M., Haq, Ui.N., \& Hunjira, I.A. (2011). Impact of Employee Empowerment on Job Satisfaction: Analysis of Pakistani Service Industry. Interdisciplinary Journal of Contemporary Research Business. 2, (11), 680-684.

Allen, D. G., Shore, L. M. \& Griffeth, R. W. (2003). The role of perceived organizational support and supportive human resource practices in the turnover process. Journal of Management, 29 (1), 99-118.

Bartunek, J.M. \& Spreitzer, G.M. (2006). The interdisciplinary career of a popular construct used in management-empowerment in the late 20th century, Journal of Management Inquiry, 15: 255-273.

Blackmore, C., \& Kuntz, J. (2011). Antecedents of job insecurity in restructuring organisations: An empirical investigation. New Zealand Journal of Psychology, 40(3), 7-18.

Blancero, D. M., Delcampo, R. G., Gao, T., And Lewis, P. D. (2009). Insight on Hispanic business professionals, perceived organizational support and psychological contracts: Report from a large scale national study. International Journal of Business Research, 9(4), 106-111.

Bowran, J. \& Todd, K. (1999). Job stressor and job satisfaction in a major metropolitan public EMS service. Pre hospital and disaster medicine 14(4), 236-239.

Brown, M.E \& Treviño, L.K. (2006). Ethical leadership: A review and future directions. The Leadership Quarterly 17:595-616.

Celik, M. (2011)."A theoretical approach to the job satisfaction", Polish Journal of Management studies.

Chen, Y.J. (2007), "Relationship among service orientation, job satisfaction, and organizational commitment in the international tourist hotel industry". Journal of American Academy of Business, 11(2), 71-82.

Colakoglu, U., Culha, O. \& Atay, H. (2010). The effects of perceived organisational support on employees' affective outcomes: evidence from the hotel industry. Tourism and Hospitality Management. 16(2), 125-150.

Dawley, D.D., Houghton, J.D., \& Bucklew, N.S. (2010). Perceived organizational support and turnover intention: The mediating effects of personal sacrifice and job fit. Journal of Social Psychology, 150(3), 238-257.

Deez, S. (2008). Resistance: would struggle by any other name be a sweet. Management Communication Quarterly. 21(3):387392.

Dinç, E. (2015). Perceived Organizational Support as a Mediator of the Relationship between Effort-Reward Fairness, Affective Commitment, and Intention to Leave. International Business Research. 8(4), 1913-9012

Dinler, A. (2010). Isparta ili otel işletmelerinde çalışanların iş doyumu ve tükenmişlik düzeyleri ile etkileyen etmenler. Yayımlanmamış Yüksek Lisans Tezi. Süleyman Demirel Üniversitesi Sağlık Bilimleri Enstitüsü, Isparta

Droussiotis, A., \& Austin, J. (2007). Job satisfaction of managers in Cyprus. European Medical Journal of Business, 2(2), 208222.

Dugguh, S.I., Ayaga, \& Dennis. (2014). Job satisfaction theories: Traceability to employee performance in organizations .IOSR Journal of Business and Management. 16(5), 11-18.

Eisenberger, S.; Huntingdon, R.; Hutchinson, S.; Sowa, D. (1986). Perceived organizational support. Journal of Applied Psychology, 71:500-507.

Elçi, M., L. \& Alpkan. (2009). “The Impact of Perceived Organizational Ethical Climate on Work Satisfaction” Journal of Business Ethics, 84, 297-311.

Elnaga, A.A. \& Imran, A. (2014). The Impact of Employee Empowerment on Job Satisfaction Theoretical Study. American Journal of Research Communication, 2(1), 13-26

Fuller, J.B., Barnett, T., Hester, K., \& Relyea, C. (2003). A social identity perspective on the relationship between perceived organizational support and organizational commitment. The Journal of Social Psychology, 143(6), 789-790.

Goodly, B. (2008). Leadership Development within the Eagle Scouts: An Investigation of the Influence of Servant Leadership Values. Doctoral. Capella University, Miami. 
Gholamreza, Borghei, Matin And Dastani. (2010), “An examination of the relationship between empowerment and organizational commitment," Academic Leadership Online Journal, 8(4) 3-6.

Haas, M.R. (2010), "The double-edged swords of autonomy and external knowledge: analysing team effectiveness in a multinational organization", The Academy of Management Journal, 53: 989-1008.

Harris C, Bianco A.T, \& Julie H. (2011). Work-family conflict, perceived supervisor support and organizational commitment among Brazilian professionals. Journal of Vocational Behaviour.

Hussami, M. (2008). A Study of nurses' job satisfaction: The relationship to organizational commitment, perceived organizational support, transactional leadership, transformational leadership, and level of education. European Journal of Science Research. 22(2): 286-295.

Islam, T., Aamir, M., Khan, S.U.R., \& Ahmad, U.N.U. (2013). Organizational learning culture, social exchange relations and multifoci citizenship behaviours: A literature survey approach. World Journal of Management and Behavioural Studies, 1 (1), 33-40.

Jaramillo, F., Mulki, J. P., \& Boles, J. S. (2013). Bringing meaning to the sales job: The effect of ethical climate and customer demandingness. Journal of Business Research, 66(11), 2301-2307.

Kim, W. G. \& Brymer, R. A. (2011). The effect of ethical leadership on manager job satisfaction commitment, behaviour outcomes and firm performance. International Journal of Hospitality Management, 30(4).

Karatepe, O. M. (2012). Perceived organizational support, career satisfaction, and performance outcomes. International Journal of Contemporary HospitalityManagement, 24(5), 735-752.

Koh, H. C. \& Boo, E. H. Y. (2004), "Organisational ethics and employee satisfaction and commitment", Management Decision, 42(5), 677-693.

Hedge, J., \& Borman, W. (2012). The Oxford Handbook of Work and Aging. New York: Oxford.

Kanter, R. (1968). A study of commitment mechanism in utopian societies. American Sociological Review, 33, $499-517$.

Khan, M. A. (2012), "Ethical Values and Work Related Outcomes: An Empirical Study of Pakistani Organizations", African Journal of Business Management, 6(11), 3977-3987.

Khorshidi, S \& Mohseni, Z. (2010)."Effects of ethical climate on job satisfaction of public and private banks in Iran", Journal of the Third Year, 7:119-79.

Khuong, M.N. \& Tien, B. D. (2013). Factors influencing employee loyalty directly and indirectly through job satisfaction - A study of banking sector in Ho Chi Minh City. International Journal of Current Research and Academic Review. 1(4), $81-95$

Kiboss. J.K \& Jemiryott, H.K.S. (2014). Relationship between Principals' Leadership Styles and Secondary School Teachers' Job Satisfaction in Nandi South District, Kenya. Journal of Education and Human Development. 3(2), 493-509.

Kouzes J. M. \& Posner B. Z. (2002). Leadership Challenge. San Francisco, CA: Jossey-Bass.

Krishnan, J. \& Mary, V.S. (2012). Perceived Organisational Support-An Overview on its Antecedents and Consequences. International Journal of Multidisciplinary Research 2(4), 1-13.

Landsberger, H. A. (1958). Hawthorne Revisited, Ithaca.

Lautizin, M., Laschinger, H.K.S \& Ravazzol, J. (2009). Work Place Empowerment, Job Satisfaction and Job Stress among Halian Mental Health Nurses: An Exploratory Study. Journal of Nursing Management, 17, 446-452.

Lopez, T.B., Babin, B.J. \& Chung, C. (2009) "Perceptions of Ethical Work Climate and Person-Organization Fit Among Retail Employees in Japan and the US: A Cross-Cultural Scale Validation", Journal of Business Research, 62, 594-600.

Malik, M., Wan, D., Dar, L., Akbar, A. \& Naseem, M.A. (2013). The Role of Work Life Balance in Job Satisfaction and Job Benefit. The Journal of Applied Business Research 30(6), 1627-1638.

Malhotra, N., \& Mukherjee, A. (2004). The relative influence of organizational commitment and job satisfaction on service quality of customer-contact employees in banking call centres. Journal of Services Marketing, 18, 162-174.

Maher, D. (2008). Interactive whiteboards and web conferencing systems in the primary school. Educational Research at Macquarie. 3: 30-31.

Man M., Modrak V., Dima I.C., \& Pachura, P. (2011). A Theoretical approach to the job satisfaction. Polish Journal of Management Studies, 4:1-25.

Mayer, D.M., Kuenzi, M., Greenbaum R., Bardes, M. \& Salvador, R.B. (2009). How low does ethical leadership flow? Test of a trickle-down model. Organizational Behavior and Human Decision Processes, 108: 1-13.

Mccauley, C. D. \& Van Velsor E. (2004). The Center for Creative Leadership Handbook of Leadership Development. San Francisco: Jossey-Bass.

Mehrabani, S.E \& Shajari, M. (2013). Relationship between Employee Empowerment and Employee Effectiveness. Service Science and Management Research (SSMR) journal. 2(4),60-68.

Michailova, S. (2002). "When common sense becomes uncommon: participation and empowerment in Russian companies with Western participation", Journal of World Business. 37: 180-7.

Mio, R-T., Hou, X-L \& Kim D. (2011). The antecedents and consequences of job satisfaction in China. Paper presented in 2011 International Symposium on Applied Economics, Business and Development. August 6-7, Dalian, China.

Monsef, S.M.S., Fadaei, M \& Pour. H.A (2014). The impact of organizational ethical climate on employee participation in knowledge management process, in guilan organization of economic affairs and finance, and tax department. Singaporean Journal of Business Economics, and Management Studies 2(6), 8-19 
Mulki, J.P., Jaramillo, F. \& Locander, W.B. (2006) “Effects of Ethical Climate and Supervisory Trust on Salesperson's Job Attitudes and Intentions to Quit", Journal of Personal Selling \& Sales Management, 26(1), 19-26.

Mulki, J., Jaramillo, J. \& Locander, W. (2008). Effect of Ethical Climate on Turnover Intention: Linking Attitudinal and Stress Theory. Journal of Business Ethics.

Nadi, M.A \& Hazeghi, F. (2010)."Structural equation modelling of relationships between ethical climate, job satisfaction and organizational commitment and intent to leave among employees in private hospitals in Shiraz," Journal of Health Information Management, 8(5), 708-699.

Njie, T.L., Fon, L.T \& Awomodu, G. (2008). Top management commitment and Empowerment of employees in TQM implementation.

Nunnally, J \& Bernstein, I. 1994. Psychometric theory. ( $3^{\text {rd }}$ Edition). New York: McGraw-Hill.

Olorunniwo, F., \& Udo, G. (2002). The Impact of management and employees on cellular manufacturing implementation. International Journal of Production and Economics. 76: 27-38.

Ongori, H. (2009). "Managing behind the scenes: A view point on employee empowerment", African Journal of Business Management, 3(1), 9-15.

Oreg, S. \& Sverdlik, N. (2011). Ambivalence toward imposed change: to conflict between dispositional resistance to change and the orientation toward the change agent. Journal of Applied Psychology. 96(2), 337-349.

Orgambídez R. A \& Borrego Y. A. (2014). Research Articles Empowering Employees: Structural Empowerment as Antecedent of Job Satisfaction in University Settings. 7(1), 28-36.

Page D. \& Wong P. T. (2000). A Conceptual Framework for Measuring Servant Leadership.

Parvin, M.M. \& Kabir, M.M.N. (2011). Factors Affecting Employee Job Satisfaction of Pharmaceutical Sector. Australian Journal of Business and Management Research, 1(9) 113-123.

Pheng, L.S., \& Jasmine, A.T. (2004). Implementing Total Quality Management in Construction firms. Journal of Management in Engineering, 20(1). 1-9.

Pieterse, A.N., Knippenberg, D.V., Schippers, M. \& Stam, D. (2010) "Transformational and transactional leadership and innovative behaviour: The moderating role of psychological empowerment", Journal of Organizational Behaviour, 31 : 609-623,

Qasim. S., Cheema. F.E. \& Syed. N.A. (2013). Exploring Factors Affecting Employees' Job Satisfaction at Work. Journal of Management and Social Sciences, 8(1), 31-39.

Randall, M.L., Cropanzano, R., Bormann, C.A., \& Birjulin, A. (1999), “Organizational politics and organizational support as predictors of work attitudes, job performance, and organizational citizenship behavior”, Journal of Organizational Behaviour, 20(2), 159-174.

Riggle, R.J., Edmondson, D.R. \& Hansen, J.D. (2009), “A meta-analysis of the relationship between perceived organizational support and job outcomes: 20 years of research", Journal of Business Research, 62(10), 1027-1030.

Rhoades, L. \& Eisenberger, R. (2002), "Perceived organizational support: A review of the literature", Journal of Applied Psychology, 87(4), 698-714.

Robins, S.P. \& Judge, T.A. (2009). Organizational Behaviour, Prentice Hall, New Jersey

Salazar, J., Pfaffenberg, C., \& Salazar, L. (2006). "Locus of Control vs. Employee Empowerment and the Relationship with Hotel Managers' Job Satisfaction”. Journal of Human Resources in Hospitality \& Tourism, 5(1); 1-16.

Sarwar. A. \& Khalid A. (2011). Impact of Employee Empowerment on Employee's Job Satisfaction and Commitment with the Organization. Interdisciplinary journal of contemporary research in business. 3(2). 664-683.

Singh, A.K., \& Singh, A.P. (2010). Role of Stress and Organizational Support in Predicting Organizational Citizenship Behavior. The IUP Journal of Organizational Behavior, 9 (4), 7-25.

Singhapakdi, A., Sirgy, M. J., Lee, D. L. \& Vitell, J. S. (2010), "The Effects of Ethics Institutionalization on Marketing Managers: The Mediating Role of Implicit Institutionalization and the Moderating Role of Socialization", Journal of Macro Marketing, 30(1), 77-92.

Shapira-Lishchinsky, O., \& Rosenblatt, Z. (2010). School ethical climate and teachers' voluntary absence. Journal of Educational Administration, 48(2), 164-181.

Schwepker, C. H. (2001), "Ethical Climate's Relationship to Job Satisfaction, Organizational Commitment, and Turnover Intention in Sales force", Journal of Business Research, 54: 39-72.

Schminke, M., Ambrose, M.L \& Neubaum, D.O. (2005) "The Effect of Leader Moral Development on Ethical Climate and Employee Attitudes", Organizational Behavior and Human Decision Processes, 97, 135-151.

Shore, L. M., \& Shore, T. H. (1995). Perceived organizational support and organizational justice. In R. S. Cropanzano \& K. M. Kacmar (Eds.), Organizational politics, justice, and support: Managing the social climate of the workplace: 149-164.

Stamper, C.L. \& Johlke, M.C. (2003), "The impact of perceived organizational support on the relationship between boundary spanner role stress and work outcomes", Journal of Management, 29 (4), 569-588.

Susskind, A.M., Borchgrevink, C.P., Kacmar, K.M. \& Brymer, R.A. (2001), “Customer service employees' behavioural intentions and attitudes: An examination of construct validity and a path model”, International Journal of Hospitality Management, 19(1), 53-77.

Tansky, W.J. \& Cohen, J.D. (2001). "The relationship between organizational support, employee development, and organizational commitment: An empirical study” Human Resource Development Quarterly, 12(3), 285-300. 
Tavitiyaman, P. (2004). The Effect of Management Commitment to Service Quality on Employees. Job Satisfaction and Prosocial Service Behaviours, 1-80

Tekleab, A.G., \& Chiaburu, D.S. (2011). Social exchange, empirical examination of form and focus. Journal of Business Research, 64, 460-466.

Tseng, F.C. \& Fan, Y.J. (2011). "Exploring the Influence of Organizational Ethical Climate on Knowledge Management", Journal of Business Ethics, 101: 325-342.

Unal, O.F. (2012). Relationship between Organizational Commitment and Ethical Climate: The Mediating Role of Job Satisfaction Dimensions (A Study in A Group Of Companies in Turkey). Journal of WEI Business and Economics $1(1), 92-105$.

Valentine, S., Gary, L., Fleischman, M. \& Kidwell, R. (2010). Corporate ethical values, group creativity, job satisfaction and turnover intention: The impact of work context on work response. Journal of Business Ethics, 98(3): 353- 372.

Vishwakarma, R.K., Shukla, A. \& Nougriaya, S. (2015). Job Satisfaction and Its Impact On Absenteeism: A Case Study Related To Teachers In Private Engineering Colleges. International Journal of Engineering Technology \& Management Research 3(1):10-15.

Wayne, S. J., Shore, L. M., \& Liden, R. C. (1997). Perceived organizational support and leader-member exchange: A social exchange perspective. Academy of Management Journal, 40: 82-111.

Yang, S \& Choi, S.O. (2009) "Employee empowerment and team performance, Autonomy, responsibility, information, and creativity", Team Performance Management, Emerald Group Publishing Limited. 15(5), 289-301.

Yoon, J. \& Thye, S.R. (2002), “A dual process model of organizational commitment: Job satisfaction and organizational support", Work and Occupations, 29(1), 97-124.

Zehir, C., Muceldili, B., \& Zehir, S. (2012). The Moderating Effect of Ethical Climate on the Relationship between Job Satisfaction and Organizational Commitment: Evidence from Large Companies in Turkey. Procedia-Social and Behavioural Sciences, 58 ,734-743. 